\title{
Fungal Endophytes of Grasses in Japan : Benefits to the Host and Problems
}

\author{
Hironori Koga
}

\begin{abstract}
Among the perennial ryegrass and tall fescue in Japan, the turf-type grasses, ecotype collections and imported grasses were found to be infected with Neotyphodium endophytes, but few commercial pasture-type grasses were infected. The occurrence of ryegrass staggers was limited to the beef cattles and cows which had been fed with the imported ryegrass straw. Therefore, it was strongly suggested that the ryegrass staggers occurring in Japan was caused by the imported endophyte-infected grasses. On the other hand, the endophyteinfected grasses showed feeding deterrence to insects such as bluegrass webworm and Tribolium confusum, and disease resistance to Bipolaris sorokiniana, Rhizoctonia solani, Drechslera dictyoides f. sp. perenne and so on. In Japan, Neotyphodium endophytes have been isolated from 27 species of cool-season grasses in 13 genera during the last three years, and most of them belonged to the subfamily Pooideae.

Among the warm season grasses, Ephelis endophytes were detected in 15 species such as bermudagrass, Pangola-grass and paragrass. Paspalum thunbergii infected with Ephelis sp. showed feeding deterrence to a rice grass hopper, and Digitaria decumbens (Pangola-grass) also had acquires tolerance to Japanese army worm (Pseudaletia separata) and grasshopper (Aiolopus thalassimus). However, the toxicity of the endophyte-infected grasses to animals is not known.

It is important to know whether non-host plants acquired the resistance to insects and plant pathogens by artificial inoculation with fungal endophytes or not, which depends on the specificity between plant and endophyte associations. Here the compatibility and incompatibility between them are discussed.
\end{abstract}

Key words : grass endophytes, Neotyphodium, Epichlö̈,

\section{Occurrence of fungal endophytes of grasses in Japan}

Perennial ryegrass and tall fescue infected with Neotyphodium endophytes are toxic to animals and showed a feeding deterrence several insect pests ${ }^{1)}$. The incidence of ryegrass staggers in beef cattles and cows has been reported in several prefectures in Japan from around $1996^{2,3}$. Therefore, the presence of endophytic fungi has been examined in commercial pasture-type and turf-type cultivars, ecotypes in Japan and in imported grasses, such as perennial ryegrass, tall fescue and meadow fescue. Neotyphodium endophytes were not detected in common commercial pasture-type cultivars of perennial ryegrass such as

Research Institute of Agricultural Resources, Ishikawa Agricultural College, Nonoichi, Ishikawa 9218836, JAPAN

Fax (076)248-4191 
Kiyosato, Friend, Yatsugane, Yatsunami, and Yatsuboku. However, it was detected in the ecotypes, collected at 2 out of 27 collection sites, and Gliocladium-like endophyte was also detected in the ecotypes at 3 out of 27 sites $^{4}$. In common commercial turf-type cultivars 13 out of 18 cultivars were infected with Neotyphodium endophytes, and they showed feeding deterrence to the bluegrass webworm ${ }^{5,6)}$.

Neotyphodium endophytes were not detected in common commercial pasture-type cultivars of tall fescue such as Nanryo, Hokuryo, Yamanami, and Manabe. Exceptionally the imported cultivar, Kentucky 31 for both pasture and turf have been reported to be infected with fungal endophytes. Fourteen ecotypes collected from 39 sites contained mycelia in the aleurone layer of seed. The wild perennial ryegrass and tall fescue in Japan are said to have derived from the plants imported from U.S.A. and Europe about 100 years ago ${ }^{7}$. Meadow fescue plants containing intercellular hyphae characteristic of Neotyphodium endophytes in their leaf sheaths were observed in seven out of eight ecotypes collected in Hokkaido, and they had acquired the resistance to oat bird-cherry aphid (Rhopalosiphum padi Linne $)^{8)}$. The percentage of infected plants ranged from 80 to $100 \%{ }^{9)}$.

Timothy plants were mainly cultivated in Hokkaido. Commercial cultivars Senboku and Hokushu infected with Epichloë typhyina showed choke symptoms at their heading stage $^{10,11)}$, and had acquired the resistance to Cladosporium phlei ${ }^{10)}$ and Puccinia graminis $\mathrm{f}$. sp. phlei-pratensis ${ }^{11)}$. Choke symptoms have also been observed in chewing fescue plants, but perithecia have not been observed in Japan ${ }^{12)}$. Neotyphodium endophyte has been isolated from 27 species of cool-season grasses in 13 genera during the past three years in Japan, and interestingly most of them belonged to the subfamily Pooideae ${ }^{13)}$.

Grayish-white, mummified panicles of Paspalum thunbergii, Eragrostis ferruginea and Pennisetum alopecuroides were observed at Nishinasuno, Tochigi prefecture (Figs. 2-3). First white streaks of fungal mass appeared on the surface of the leaves of Paspalum thunbergii (Fig. 1). The healthy plants had loose panicles (Fig. 4), but the diseased plants had panicles which were glued into a cylindrical structure and covered with white sclerotioid masses (Fig. 2). The color of the stroma became darker as the disease progressed (Fig. 3). Numerous acicular hyaline conidia were formed on the sclerotioid masses on the spikelets and glumes, and the conidia were $8-20 \times 0.8-1.4 \mu \mathrm{m}$ (Fig. 5). Ten or more days were required for the development of colonies from the pieces of panicles or stems on potato dextrose agar (PDA) medium. The colonies were whitish to buff in color. The colonies grew slowly and the optimal temperature for growth was around $25^{\circ} \mathrm{C}$. The conidia formed on the colonies (Fig. 8) were the same in shape and size as those observed on the mummified panicles. Examination of panicles and stems using a scanning electron microscope confirmed the presence of ephedial conidia formed on the sclerotioid masses on the spikelets and glumes and inside of them (Figs. 5-6). The ephedial conidia were observed in the cells of stems (Fig. 7). The morphology of the conidia, and the appearance of the colonies isolated from these plants were identical to those described for Ephelis sp. ${ }^{14}$.

Tsukiboshi et al. ${ }^{15}$ isolated Ephelis sp. from 12 species of grasses such as Brachiaria mutica (paragrass), Chloris barbata, Chloris divaricata, Chrysopogon aciculatus, Cynodon dactylon (bermudagrass), Cynodon pletostachyrus, Digitaria decumbens (Pangola-grass), Digitaria violascens, Imperata cylindrica. var. koenigii, Leptochloa panicea, Miscanthus sp. and Paspalum scrobiculatum in Okinawa prefecture. As Brachiaria mutica (paragrass), Cynodon dactylon (bermudagrass), Cynodon pletostachyrus and Digitaria decumbens (Pangola-grass) are important grasses for pasture and turf, it is expected that the plants will be conferred the 

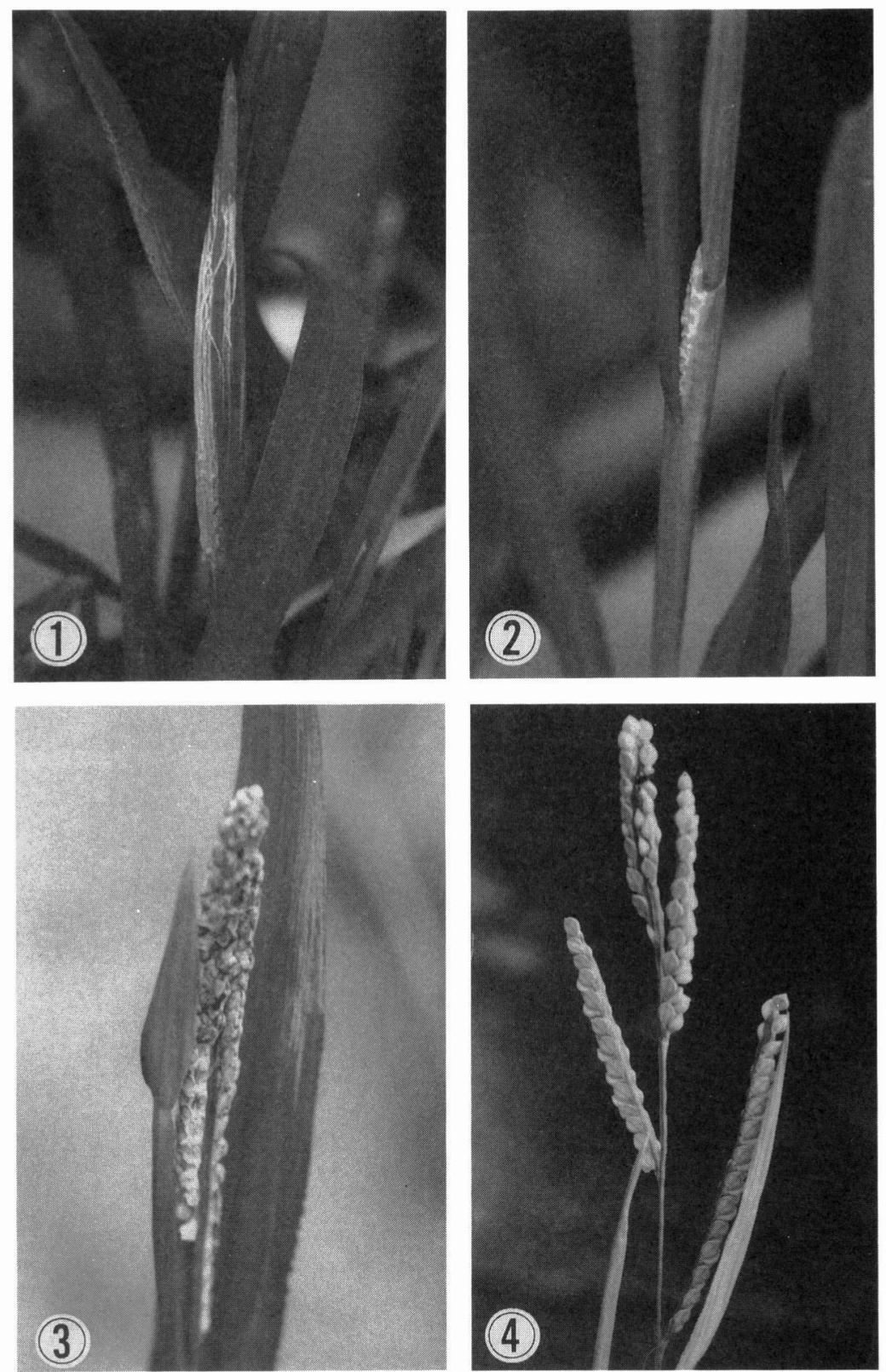

Figs. 1-4 Symptoms of black choke in Paspalum thunbergii Kunth ex Stud. Fig. 1. White streaks of fungal mass on the leaf surface. Fig. 2. White mummified panicles in the sheath. Fig. 3. Grayish-white, mummified panicles glued into a cylindrical structure. Fig. 4. The healthy plant with a loose panicle.

tolerance to insects and drought by artificial infection with Ephelis sp.

Ephelis was believed to be the anamorph of Balansia. Tanaka et al. ${ }^{16)}$ analyzed variation in nuclear ribosomal DNA ITS region in Ephelis spp. obtained from different hosts and 

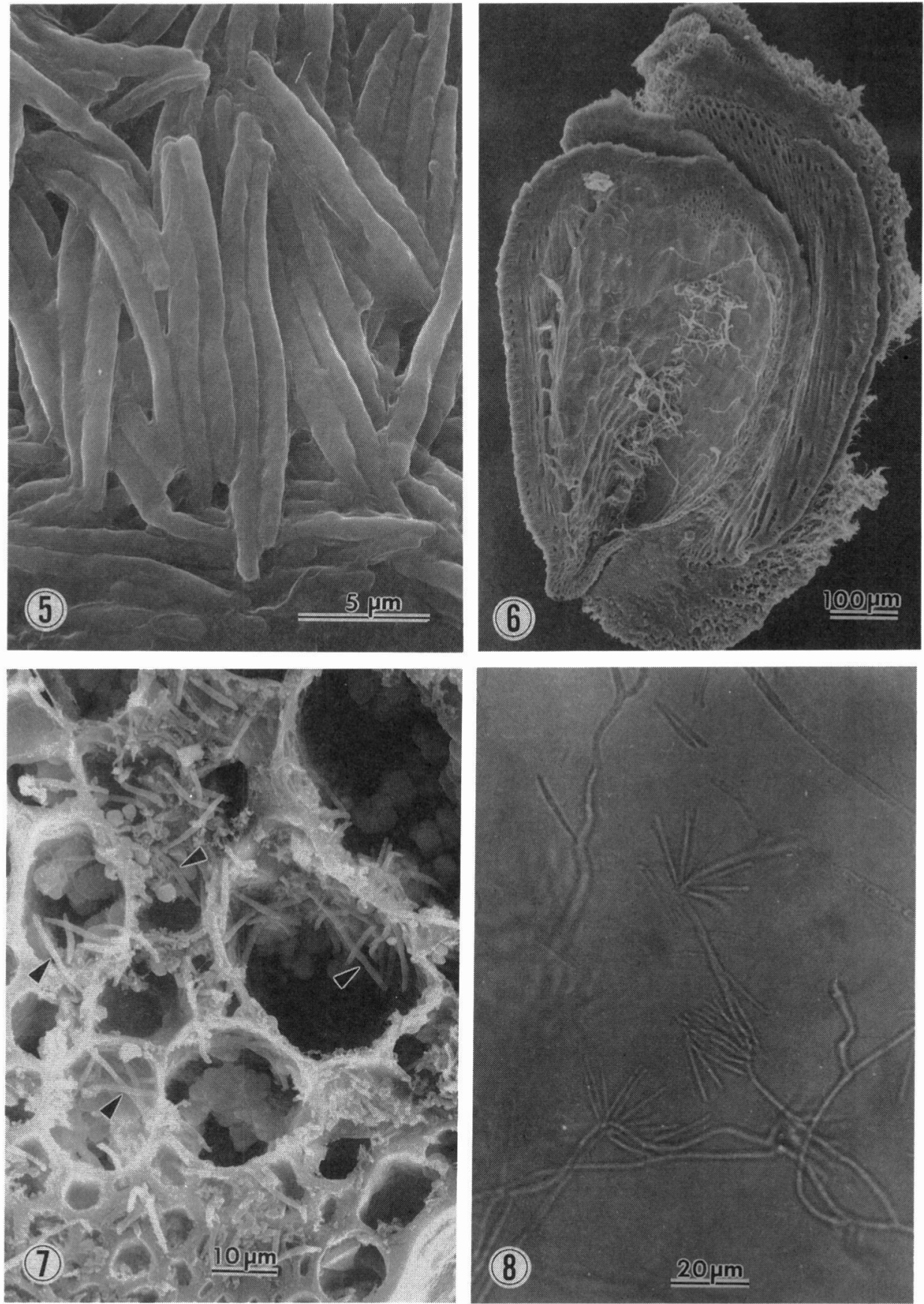

Fig. 5 Scanning electron micrograph of the surface of mummified panicles of Paspalum thunbergii Kunth ex Stud. Fig. 6 Transverse section of mummified panicles of Paspalum thunbergii. Fig. 7 Transverse section of the stem of Paspalum thunbergii with the mummified panicle. The ephedical conidia (arrow) were observed in the parenchymatous cells inside of the stem. Fig. 8 Light micrograph of conidia formed on the colony isolated from the mummified panicles of Paspalum thunbergii. 
locations, and clarified that 33 isolates of Ephelis spp. belonged to the same cluster, but were different from those of Balansia spp. From these results, they proposed that Ephelis would not be the anamorph of Balansia.

\section{Tolerance to herbivorous insect}

The larvae of the bluegrass webworm (Parapediasia teterrella Zincken) feed on the sprouts of turf grasses and cause severe damage to them all over Japan except in the northern part of the country. Kanda et al. ${ }^{5}$ reported that both perennial ryegrass and tall fescue infected with Neotyphodium endophytes had showed feeding deterrence to bluegrass webworm. The plants artificially infected with the endophytes also showed feeding deterrence to the bluegrass webworm ${ }^{17)}$. It was confirmed that meadow fescue infected with Neotyphodium uncinatum had acquired the resistance to oat bird-cherry aphid (Rhopalosiphum padi Linne $)^{8}$. Recently, Yoshimatsu et al ${ }^{18)}$ clarified that endophyte-infected seeds of ground tall fescue had inhibitory effects on the population growth of the confused flour beetle, Tribolium confusum Jacquelin (Coleoptera : Tenebrionidae).

Among the warm season grasses, Paspalum thunbergii infected with Ephelis sp. (Figs. 18) showed feeding deterrence to a rice grasshopper ${ }^{19}$ ), and Digitaria decumbens (Pangolagrass) had tolerance to Japanese army worm (Pseudaletia separata) and to a grasshopper (Aiolopus thalassimus) $^{20)}$.

\section{Disease resistance}

Timothy plants infected with Epichloë typhina had acquired the resistance to Cladosporium phlei $i^{10)}$ and Puccinia graminis f. sp. phlei-pratensis ${ }^{11)}$. The antifungal substances were isolated from stroma of the timothy infected with Epichlö̈ typhina and sesquiterpenoids, chokol $A$ to $\mathrm{G}^{21)}$ and several kinds of fatty acids have been identified ${ }^{22}$. Perennial ryegrass infected with Neotyphodium endophyte has been reported to be resistant to Bipolaris sorokiniana ${ }^{23)}$, Rhizoctonia solani, Drechslera dictyoides f. sp. perenne and Pyricularia grisea ${ }^{13)}$ in Japan.

\section{Animal toxicities}

Ryegrass staggers of beef cattles and cows has been suspected to be induced by consumption of imported grasses called ryegrass straw in 7 prefectures in Japan ${ }^{2}$. These animals had been fed the ryegrass straw imported from U. S. A. When the ryegrass straw was not fed to the animals, they recovered from ryegrass staggers. The ryegrass straw was highly infected with Neotyphodium endophytes, and contained 1,100-3,700 ppb lolitrem B and 4001,300 ppb ergovaline. Therefore, the imported ryegrass straw was strongly suspected as the cause of the ryegrass staggers ${ }^{2,3}$.

\section{Specificity between plant endophyte associations}

In several useful grasses such as bentgrass, Kentucky bluegrass, zoysia, and mascarene grass, natural infection with fungal endophytes has not been detected. Therefore, attempts have been made to infect these grasses artificially with fungal endophytes ${ }^{24}$. Imada et al. ${ }^{25)}$ 
succeeded to infect rough bluegrass plants with Neotyphodium endophyte, and the infected plants showed feeding deterrence to bluegrass webworm. Creeping bent has been successfully infected with Neotyphodium endophytes ${ }^{26)}$. When the endophytes were artificially inoculated into the non-host plants, some of them were infected, but the others were not. Whether the infection was successful or not depends on the specificity between plant and endophyte associations. It has already been reported that the intercellular matrix between the hyphae of the endophyte and host cell wall degenerate in an incompatible association of Neotyphodium coenophialum and perennial ryegrass ${ }^{27)}$. In an other incompatible plantendophyte association, the frequency of infected vascular bundles and the density of hyphae in them were very high in stunted plants inoculated with Epichloë festucae ${ }^{28}$. The types of incompatibility would be various. Further studies on the mechanism of specificity will be important to successfully inoculate the grasses with the endophytes.

\section{References}

1) Siegel M.R., Latch G.C.M., and Johnson M.C. (1987) Fungal endophytes of grasses. Ann. Rev. Phytopathol. 25, 293-315.

2) Miyazaki S. (1998) Animal toxicities caused by alkaloids produced by fungal endophytes. J. Clinic. Vet. Med. 16 (No.5), 34-40 (in Japanese).

3) Nakamine M., Yasuzato H., Koshimoto H., Ono M., Nakamura M., Nitta Y.,Shouji K., Shirai Y., and Miyazaki S. (1998) Suspected cases of rygrass stagger caused by consumption of rygrass-straws infected with fungal endophtes. J. Clinic. Vet. Med. 16 (No.11), 38-45 (in Japanese).

4) Koga H., Kimigafukuro T., Tsukiboshi T., and Uematsu T. (1993) Incidence of endophytic fungi in perennial ryegrass in Japan., Ann. Phytopathol. Soc. Japan 59, 180-184

5) Kanda K., Hirai Y., Koga H., and Hasegawa K. (1994) Endophyte-enhanced resistance in perennial ryegrass and tall fescue to bluegrass webworm, Parapediasia teterrella. Jpn. J. Appl. Entomol. Zool. 38, 141-145 (in Japanese with English abstract).

6) Fukami M., Yokoyama T., Shingyouji T., Koga H., Akiyama F., Tsukiboshi T.,Uematsu T., and Fujiie A. (1997) Simple and rapid detection of endophytic fungi from perennial ryegrass seeds by vise blotting ELISA procedure. J. Japanese Soc. Turfgrass Sci.26, 19-24.

7) Koga, H., Tsukiboshi T., and Uematsu T. (1995) Incidence of the endophytic fungus Acremonium coenophialum in tall fescue (Festuca arundinaceae) in Japan. J. Japan. Grassl. Sci. 40, 373-380.

8) Kanda K., Koga H., and Hirai Y. (1992) Resistance of Acremonium endophyte-infected grasses to oat bird-cherry aphid, Rhopalosiphum padi Linne. Proc. Kanto-Tosan Plant Protec. Soc. 39, 191-192 (in Japanese).

9) Koga H., Tsukiboshi R., and Uematsu T. (1994) Incidence of the endophytic fungus, Acremonium uncinatum, in meadow fescue (Festuca pratensis) ecotypes in Hokkaido. Bull. Natl. Grassl. Res. Inst. $49,37-43$.

10) Shimanuki T. (1987) Studies on the mechanisms of the infection of timothy with purple spot disese caused by Cladosporium phlei (Gregory) de Vries. Res. Bull. Hokkaido Natl. Agric. Exp. Stn. 148, 156 (in Japanese with English abstract).

11) Tajimi A. (1991) Acremonium endophytes as a tool of biocontrol. Plant Protection 45, 106-108 (in Japanese).

12) Koga H., Tsukiboshi T., Uematsu T., Shimanuki T., and Tajimi A. (1998) Occurrence of choke diseases of chewing fescue and slender false brome grass in Japan. Bull. Natl. Grassl. Res. Inst. 57, 27-34 (in Japanese with English abstract).

13) Shimanuki T. (1999) Endophyte-infected grasses and their disease resistance. Proceeding of 2nd Endophyte Research Meeting. National Grassland Research Institute (in Japanese).

14) Koga H., Tsukiboshi T., and Nakayachi O. (1998) Occurrence of black chokes of Eragrostis ferruginea (Thunb.) P. Beauv. and Pennisetum alopecuroides (L.) Spreng. caused by Ephelis sp. in Japan. Bull. RIAR, Ishikawa Agr. Coll. 6, 45-52. 
15) Tsukiboshi T., Takahashi K., Uegaki R., Kobayashi M., Okumura K., and Shimanuki T. (1998) First report of black choke disease of 13 species of warm-season grasses caused by Ephelis sp. Japan. Ann. Phytopathol. Soc. Japan 63, 496 (in Japanese).

16) Tanaka E., Kawasaki S., Tanaka C., Tsukiboshi T., Peng Y.-L. and Tsuda M. (1999) Variation in nuclear ribosomal DNA ITS region in Ephelis spp. obtained from different hosts and locations. Ann. Phytopathol. Soc. Japan 65, 414 (in Japanese).

17) Koga H., Hirai Y., Kanda K., Tsukiboshi T., and Uematsu T. (1997) Successive transmission of resistance to bluegrass webworm to perennial ryegrass and tall fescue plants by artificial inoculation with Acremonium endophytes. JARQ 31, 109-115.

18) Yoshimatsu S., Arimura K., and Shimanuki T. (1998) Comparison of population growth rates of confused flour beetle, Tribolium confusum Jacquelin (Coleoptera: Tenebrionidae), on endophyteinfected or endophyte-uninfected seeds of ground tall fescue and perennial ryegrass. Jpn. J. Appl. Entomol. Zool. 42, 227-229 (in Japanese with English abstract).

19) Uegaki R., Koga K., Kanda K., Shimanuki T., and Kobayashi R. (1997) Endophyte-enhanced resistance to locust in Paspalum thunbergii Kunth. Abstracts of Papers of Annual Meeting of Japanese Society of Turfgrass Science. 90-91 (in Japanese).

20) Takahashi K., Christensen M.J., Kohno K., Tsukiboshi T., and Kobayashi M. (1999) A fungal epiphyte (Ephelis sp.) of grasses on Ishigaki island and its effect on the feeding of insect pests. Abstracts of Papers of Annual Meeting of Japanese Society of Insect Science (in Japanese with English abstract).

21) Koshino H., Yoshihara T., Sakamura S., Shimanuki T., Sato T., and Tajimi A. (1989) Novel C-11 epoxy fatty acid from stromata of Epichloë typhina on Phleum pratense. Agric. Biol. Chem. 53, 25272528.

22) Koshino H., Togiya S., Terada S., Yoshihara T., Sakamura S., Shimanuki T., and Tajimi A. (1989) New fungitoxic sesquiterpenoids, Chokols A-G, from stroma of Epichlö typhina and the absolute configuration of chokol E. Agric. Biol. Chem.53, 789-796.

23) Koga K., Tsukiboshi T., and Uematsu T. (1995) Endophyte-enhanced resistance to plant pathogens in perennial ryegrass. J. Japanese Soc. Turfgrass Sci. 24, 44 (in Japanese).

24) Latch G.C.M., and Christensen M.J. (1985) Artificial infection of grasses with endophytes. Ann. Appl. Biol. 107, 17-24.

25) Imada T., Hiruma N., and Shinozaki, S. (1997) Infection of Neotyphodium endophytes into rough bluegrass. Plant Breeding 47 (Sup. 2), 133 (in Japanese).

26) Sun S., and Brede A.D. (1997) Inoculation of creeping bent with Acremonium endophyte. International Turfgrass Society Research Journal 8, 925-929.

27) Koga H., Christensen M. J. and Bennett R. J. (1993) Incompatibility of some grass-Acremonium endophyte associations. Mycol. Res. 97, 1237-1244.

28) Christensen M.J., Ball O.J.-P., Bennet R.J., and Schardl C.L. (1997) Fungal and host genotype effects on compatibility and vascular colonization by Epichloë festucae. Mycol. Res. 101, 493-501. 